\title{
Determining the Critical Factors Affecting Tour Operator Reputation Based on Stakeholders' Perceptions: Reputation Quotient Approach
}

\author{
Ghada Khairat \\ Azza Maher \\ Tourism Studies Department, University of Sadat City
}

\begin{abstract}
In today's highly competitive, dynamic and turbulent business environment, tour operators strive to search for ways to differentiate their offerings and build favorable relationships with company's stakeholder groups. Reputation is an important mean by which tour operators can maintain a sustainable competitive advantage and ensure a long term relationship with multiple stakeholder groups. A good feeling about a tour operator, its activities, workplace, past performance and future prospects by key stakeholders can lead to a positive stakeholder's decision about the tour operators. More favorable reputation increase organization performance and attract investors, customers and high-performance employees. Moreover, it enhances customer and employee's loyalty. Thus, in order to manage corporate reputation, it is necessary to establish sound reputation measurement mechanisms, which inform tour operators of the reputation perceptions which limit or enhance their ability to attract a particular form of support from their stakeholders. The purpose of this study is to explore the most important factors that determine the link between tour operators' corporate reputation and stakeholders' decisions regarding cooperation in services providing or supporting the operations of a company. In this context, hotels are chosen as the most important stakeholder in tour operator business. In order to achieve the objectives of the study, a model is developed based on the Corporate Reputation Quotient (CRQ) approach. This model is transformed into a questionnaire and 197 hotels' managers have been asked through this questionnaire to identify the most important factors that lead to the creation of the tour operators' corporate reputation. The results determine that the "Financial Performance" factor leads to a more favorable reputation. Moreover, concentrating on the "Vision and Leadership" factor can result in a positive perception of the company. On the other hand, the "Emotional Appeal" and "Social Responsibility" factors do not increase the diagnostic value of the corporate reputation. The results also show that there is a significant difference between hotels' categories (four or five stars) in their perception of the importance of the corporate reputation factors with respect only to the "Products and Services", "Vision and Leadership", and "Workplace Environment". Finally, there is a significant difference between hotels' gross revenue with respect only to the factors "Products and Services" and "Vision and Leadership" of tour operator reputation.
\end{abstract}

Keywords: Corporate Reputation, Tour Operators, Reputation Management, Stakeholders, Reputation Measurement, Reputation Quotient.

\section{Introduction}

Reputation is an important asset which could be used as a competitive advantage and a source of financial performance. A good reputation is identified as an intangible resource which may provide the organization with a basis for sustaining competitive advantage given its valuable and hard to imitate characteristics. Benefits of a good reputation are seen as including higher customer retention rates and its associated increased sales and product selling prices, and reduced operating costs. Reputation defined as "a perceptual representation of a company's past actions and future prospects that describe the firm's overall appeal to all its key constituents when compared to other leading rivals".,

Corporate reputation generates value to tour operators, as it plays a significant role in organization-constituent interactions. Specifically, stakeholders may rely on the reputation of tour operators when making decisions. In other words, such reputation informs customers about what services to purchase, employees about what company to work for, or investors about what stocks to invest in. In addition, reputation directs suppliers to accept the operation of the tour operator.

Furthermore, tour operators with good reputations are able to charge premium prices for their services by signaling product and service quality. They also benefit from higher employee identification and employee morale to act consistently and convey the corporate values. Corporate reputations are also important in gaining leverage in negotiations with suppliers, creditors, and investors. ${ }^{5,6}$ Successful tour operators are aware of the importance of reputation. A positive reputation brings trust, ${ }^{7}$ confidence, and sales, which are ultimately reflected in revenue growth and profitability. A bad reputation can lead to a decrease in consumer confidence, and, in turn, a reduction in revenue and profits. A tour operator's ultimate survival may well depend on developing and maintaining a recognizable image and favorable reputation. ${ }^{8}$ It takes 20 years to build a reputation and five minutes to ruin it. ${ }^{\mathbf{9 1 0}}$ The tour operators could achieve favorable levels of corporate reputation through being reliable, credible, trustworthy ${ }^{11,12}$, and responsible in the market in the eyes of their stakeholders. ${ }^{13}$

Also, tour operators should be creative and different. In order to do that they are supposed to consider the following: to be able to sustain their entity in the face of competitors, to have position in the sector, to present value in the 
products and services that have been offered for ensuring profit, and to achieve reliability and honesty. The corporate reputation has been considered as a competition tool that can reveal such differences. ${ }^{14}$ Furthermore, corporate reputation management and the closely linked stakeholder management approach are topics that have been attracting growing interest in recent years. A corporate reputation is a collective idea that describes the aggregate perceptions of multiple stakeholders about a company's performance; it is "a synthesis of the opinions, perceptions, and attitudes of an organization's stakeholders". In this context, a stakeholder can be defined as "any group or individual who can affect or is affected by the achievement of an organization's purpose". This interpretation highlights the close link between reputation management and the stakeholder approach. The tourism industry, as any other service industry, sells intangible products characterized mainly by being inseparable, perishable and heterogeneous. Firms in the services or experience industry, and tourism are one of them; they should invest more in developing their image and reputation. Furthermore, due to the inseparability and heterogeneity nature of the tourism products, customers are keener to select tourism service providers upon their reputation. ${ }^{15}$ Tour operators have to face the potential and ubiquitous danger of losing their good reputation through negative evaluations. ${ }^{16}$ The measurement of corporate reputation is a growing issue for practitioners and academics. There is an obvious lack of studies especially on the development of corporate reputation measurements for tour operators. Therefore, this study aims to explore the most important factors that determine the link between tour operators' corporate reputation and stakeholders' decisions to engage in a particular form of supportive behavior for a company.

\section{Literature Review}

\section{Reputation concept}

Reputation has become a strategic asset for tour operators. Business with good reputation is able to differentiate itself and retain customers and employees, and at the same time achieve higher levels of satisfaction and loyalty towards their services. Moreover, reputation is essentially the external assessment of a company held by external stakeholders. It includes several dimensions, such as an organization's perceived capacity to meet those stakeholders' expectations, the rational attachments that a stakeholder forms with an organization, and the overall net image that stakeholders have of the organization. ${ }^{17}$

Reputation is also important and valuable because it imparts confidence in the tour operator and people feel good about buying products and services. At the same time, a reputation is of considerable strategic value as it calls attention to the tour operator's attractive features. In addition, it provides companies with a competitive advantage by attracting more, and possibly higher caliber, applicants. ${ }^{10}$ In addition, reputation entails two main components, namely: (1) perception: how the company is perceived by all stakeholders; (2) reality: the truth about the company's policies, practices, procedures, systems, and performance. ${ }^{18}$ Reputation can be managed by influencing each individual stakeholder's images or impressions that are based on his or her evaluation of the company's continuous performance and communication, which again are based on the expectations from the company compared to other competitors. ${ }^{19,20,21}$ On one hand, reputation from the perspective of the company is an intangible asset that allows the company to better manage the expectations and needs of its various stakeholders, creating differentiation and barriers vis-à-vis its competitors. On the other hand, from the perspective of stakeholders, reputation is the intellectual, emotional and behavioral response as to whether or not the communications and actions of a company resonate with their needs and interests; it is to the extent that stakeholders who believe that the company meets their needs better than its competitors will behave toward it in desirable ways, e.g. invest, join, support, etc. As companies meet the needs and interests of stakeholders over time, they increase their reputation resilience and diminish their reputation risk. ${ }^{22,23}$ Corporate reputation is defined as a collective assessment of a firm's ability to provide valued outcomes to a representative group of stakeholders. ${ }^{24,25,26,27}$

Given the above discussion, corporate reputation can be perceived as the shared sum of stakeholders' images and their evaluation of how their expectations are met over time, based on a company's actions and communication compared to its competition. Corporate Reputation is both conceptualized as a perceptual construct, in terms of perceptions of a company's past actions, as well as an attitudinal construct, in terms of a firm's appeal. Both perceptions and attitudes are developed through stakeholder experience of companies. These experiences are judged in terms of stakeholders' expectations. Therefore, expectations are important moderators between stakeholders' experiences and perceptions of corporate reputation. ${ }^{28}$ Corporate reputation of tour operator is the prestige maintained through time which, based on a set of shared values and strategies and through the eminence achieved with each stakeholder, assures the sustainability and differentiation of the company via the management of its intellectual capital. ${ }^{22}$

\section{Reputation Management}

Reputation management is the process of tracking an entity's actions and other entities' opinions about those actions, reporting on those actions and opinions, and reacting to that report creating a feedback loop. ${ }^{29}$ The major components of the reputation management are: A) a genuine preoccupation with reputation; B) definition of reputation platform; C) strategic self-presentation; D) differentiation. ${ }^{30}$ Most of the reputation management is focused on pushing down negative search 
results. Furthermore, the reputation management may attempt to bridge the gap between how a company perceives itself and how others view it. ${ }^{31}$ Reputation management also treats corporate image as a corporate asset; it is to be shaped, nurtured, protected and used. ${ }^{32}$

The objective of reputation management consulting is to maintain a favorable reputation in the workplace and marketplace, enhance and build the organization's good name and reputation, establish acceptable practices, policies, procedures, systems and standards that will avoid damage to the organization's reputation, establish guidelines for dealing with situations where the company's reputation has been tarnished, and prepare and equip the management team to take full responsibility for managing the company's reputation. ${ }^{18}$ Furthermore, the role of reputation management is explored with a three-step plan proposed: a diagnostic review of the company's current identity, images, and reputation, a strategic analysis of trends, plans, and competitor positioning that defines the company's desired future state, and a review of the company's plans for managing the transition to a future desired state. ${ }^{33,34}$

\section{How tour operator reputation is formed?}

Reputation about tour operator can be based on a variety of sources. Some stakeholders may rely on direct experience they have with an organization in the form of a company's products, services, and employees. Others may rely on other indirect sources to form their perceptions, such as employees' behavior and communication, individuals' experiences with the company, the company's self-presentations, the company's uniqueness, identity-shaping practices maintained over time, media interpretations of the company, word of mouth, competitors, and rumors. ${ }^{9,35}$ Moreover, ${ }^{36}$ assured that the two main sources of tour operator reputation are experience and information or knowledge. A favorable reputation requires more than just an effective communication effort; it requires an admirable identity that can be molded through consistent performance, usually over many years. ${ }^{37}$

Reputation is also formed by internal structures and statements that define codes, strategic plans, mission or vision statements or corporate brand value propositions that clearly state what the company stands for. ${ }^{10}$ Generally, tour operator reputation is built by products and services, financial performance, vision and leadership, management and employees, and social responsibility. Each of these components produces images in the minds of various stakeholders. ${ }^{34}$ Furthermore, ${ }^{33}$ explores how reputations can be shaped and changed in the public's mind through the media, corporate rankings, contests, products, and leadership and quality awards. Also, ${ }^{38}$ describes how different stakeholders get their perceptions that ground the corporate reputation for a specific company depending on personal contact, word of mouth, prior experience, advertising, media comment, price points, direct mail, and design.

\section{The Principals of Tour operator Corporate Reputation}

The key principals of corporate reputation as mentioned by ${ }^{39,40,41,42}$ are as follows:

1. Distinctiveness: strong reputations result with a company's distinctive position in the minds of resource-holders or consumers. Much of this attribute is often related to the company's brand positioning and marketing efforts, but its believability is directly linked to the other principals

2. Authenticity: strong reputations arise when companies are genuine. Companies must 'walk the talk' in their media relations and corporate performance and governance. This is the area where many companies falter and find their reputations and profits flagging as a result

3. Transparency: strong reputations develop when companies are transparent in their business affairs. This means lots of communication, creating highly visible presences across whatever media is available to them, and engaging stakeholders in continuing dialogs

4. Consistency: strong reputations result when companies focus their actions and communications around a core theme. This almost single-minded focus, when continued over time, builds a belief presence in the mind of the stakeholder that companies will do in the future what they did in the past

5. Visible: strong reputations develop when company communicates appropriately with employees, carries out visible stakeholder initiatives, and participates in valued social/community initiatives

\section{The Importance of Corporate Reputation}

Corporate reputation creates distinctive value for the tour operator and enables it to gain competitive superiority in the market. ${ }^{14} \mathrm{~A}$ good reputation helps to manage favorable relationships (satisfaction and loyalty) with customers. It also influences customers' purchase decisions regarding service and product quality. Furthermore, it encourages a positive relationship with employees and enhances employee's loyalty by enabling a favorable identity for themselves. ${ }^{35}$ It also increases the willingness of employees to corporate with unusual requests and by fostering teamwork and a sense of shared destiny. Moreover, when managers and employees perceive that the organization has a good reputation, they feel more secure and happy, which leads to organizational loyalty. In addition ${ }^{25}$ indicates that employees' view of positive perception is likely to influence their willing to remain with the company. Specifically, talented people are more likely attracted by 
high performing and reputable companies. ${ }^{10,43}$ consistently with ${ }^{44}$ have argued that the employee's reputation perceptions of the organization's actions toward its various stakeholders influence the employee's intention to remain or leave the firm. Furthermore, company reputation affects investors' perception of a company's value. Investors are willing to pay more for the stock of a company that has a good reputation. ${ }^{\mathbf{4 5 , 4 6}}$ Also corporate reputation has a positive effect on financial performance. ${ }^{36}$ In addition, a favorable corporate reputation can greatly benefit tour operators in other ways, including allowing easier entry to new markets and brand extensions, supporting sustainability within a market, charging premium prices for products, ${ }^{47}$ attracting higher-quality and larger amounts of investments from the stock market, maintaining a high spirit among employees, contracting lower costs with suppliers, enabling successful mergers and acquisitions, and supporting and enhancing new products' introduction and recovery strategies in the event of a crisis. ${ }^{39,48}$ In sum, the value of a good reputation continues to grow largely because of the competitive advantage and market differentiation it delivers: higher sales generated by satisfied customers and their referrals ${ }^{44}$, relationships with the right strategic and business partners, lower cost of capital ${ }^{49}$, benefit of the doubt by stakeholders if crisis strikes, spread of positive word of mouth, potential to raise capital and share price ${ }^{\mathbf{1 0}}$ and suppliers who are less likely to demand payment in advance. ${ }^{\mathbf{5 0 , 5 1}}$

\section{Factors affecting corporate reputation}

Many studies highlighted the major elements that affect corporate reputation; this includes: organizational ethics, good competitive positioning, shareholder value, corporate branding activities, corporate policy and organizational structure, innovation and creativity, marketing mix activities, customer service satisfaction, full compliance with statutory regulations, employee satisfaction and loyalty, public relations and effective communication, and finally relationships with stakeholders. ${ }^{52}$ Also, tour operator reputation is affected by other factors; personal reputation affects corporate reputation as the reputation of the leader or the owner affects the reputation of an organization. ${ }^{\mathbf{9}}$ In addition, ${ }^{\mathbf{5 3}}$ demonstrates how a company's corporate reputation is influenced by external as well as internal factors. External forces include political, economic, social, technological, and competitive issues. Internal factors all interrelated involve the company's behavior, communication, and symbolic efforts.

\section{Stakeholders}

Stakeholders are defined as "any group or individual who can affect or is affected by the achievement of the organization's objectives." This new perspective means that the success of an organization is important for and measured by all stakeholders. Consequently, the goal should be value creation by following all the stakeholders' interests. Therefore, within today's perspective, the strategic handling of an organization's stakeholders is crucial to ensure beneficial relationships with all of them, which in turn again determines the company's reputation. An added complexity is the interconnectedness of stakeholders as generically described in Figure (1) including customers, employees, suppliers, investors, communities, government, media and others. The stakeholders' interconnectedness and their mutual influence on each other is a crucial element in the reputation building process and in the success of a corporation's operations. ${ }^{19}$ Those groups are internal and external. On one hand, internal stakeholders include shareholders and employees because they own or work for the business. On the other hand, external stakeholders include customers, investors, communities, suppliers and partners, creditors and the government. ${ }^{54}$ this distinction depends on the power and influence they have on the organization. ${ }^{55}$ Thus, to measure the reputation of a corporation, stakeholders who directly experience the products or services of the corporation are the crucial measurement elements. The perception of stakeholders is the yardstick of a corporation's reputation that has an immediate as well as long-term impact on the competitiveness of the corporation against its competitors in the market. ${ }^{39,56}$ The company with the good reputation becomes the first choice among stakeholders. ${ }^{34}$ However, stakeholders evaluate companies based on a number of marketing and accounting signals indicating performance, institutional signals indicating conformity to social norms and strategy signals indicating strategic postures. ${ }^{24}$

The tourism industry comprises a complex network of stakeholders. Suppliers are one of the most immediate external stakeholders that a company must consider. Suppliers have become more critical stakeholders in the early $21^{\text {st }}$ century. More often, companies build a number of small, loyal relationships with suppliers and associates. This enables each business to develop shared goals, vision and strategies. Trade buyers and sellers can effectively collaborate to deliver the best value to end customers, which is beneficial to each supplier. Additionally, tourism suppliers expect a company that operates ethically to avoid tarnishing the reputation of the companies with whom their business associates. ${ }^{7}$ 


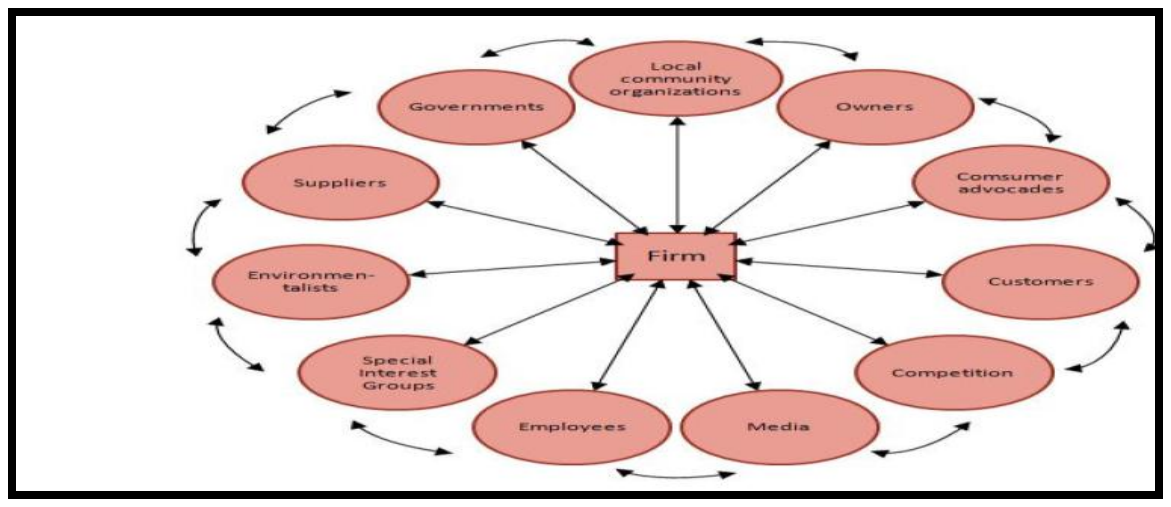

Figure (1): Stakeholder's map (Jankovicz, 2010, p. 9)

Hotels have been considered as the most important stakeholders (suppliers) for measuring tour operators' reputation. Hotels value the success of the tour operators' reputation through a list of factors: Success of their relationship, formality of the relationship, guarantees, contract, commitment in terms of pricing, reservation, cancellation and no-show, payment and issuing of vouchers ${ }^{58}$, tour operators using their best endeavors to sell the hotels and represent them in their markets ${ }^{59}$, trust, conflict resolution, coordination, information exchange, communication quality, financial performance, vision and leadership, management and employees, social responsibility, and the competitive positioning in the market. ${ }^{58}$

\section{Measuring corporate reputation}

A review of the existing models of corporate reputation measurement reveals a relatively small number of widely used models. The most prominent used methods are Fortune's Most Admired Companies (FMAC) and Reputation Quotient (RQ). Also popular, but to a lesser extent, are models such as the Corporate Personality Scale (CPS), the Stakeholder Performance Indicator and Relationship Improvement Tool (SPIRIT). ${ }^{\mathbf{6 0 6 1 , 6 2}}$ These models differ from one another according to their underlying approach, the stakeholders they survey, and what they measure. Thus, it is important to consider when it is appropriate to use which measure. However, the Reputation Quotient is most often applied. ${ }^{\mathbf{6 3 , 6 4}}$ On the other hand ${ }^{23,49,65,66}$ have added other methods of the most commonly used survey instruments to measure corporate reputation, such as RepTrak. Moreover, there are three main types of perceptions to measure corporate reputation, namely those relating to: (1) social expectations reflected in the Fortune's Most Admired Companies and the Reputation Quotient; (2) corporate personality (Corporate Personality scale) and (3) trust (Corporate Credibility scale). ${ }^{67,68}$

\section{Reputation Quotient (RQ)}

The measurement of reputation should comprise components of various roles/functions which society expects from companies, including an emotional component. Also, the Reputation Quotient is the most well-known measurement for corporate reputation from the viewpoint of the corporate social role perspective, overcoming many disadvantages of the existing reputation measurements focusing on a corporate role. The RQ presents corporate reputation with a ranking comparison with other companies and shows their uniqueness and differences with an emphasis placed on the (expected corporate role) attributes. ${ }^{\mathbf{6 9}, 70}$ Reputation Quotient (RQ) has been used world-wide since 1999 for comparative reputation studies, i.e. benchmarking. It enables the identification of critical success factors for corporate reputation from the points of view of different stakeholder groups. ${ }^{71}$

Furthermore, RQ is considered a method of qualitative measure specifically built to catch the perceptions of each group of stakeholders (consumers, investors, employees, competitors or key influencers). ${ }^{72}$ The quotient is the result of an appropriate combination of six conceptual dimensions that are evaluated. ${ }^{23}$ The RQ model measures perceptions of an organization in terms of social expectations of six dimensions such as products and services, emotional appeal, vision and leadership, financial performance, workplace environment, and social responsibility ${ }^{63}$.

Broadly speaking, the six dimensions of the Reputation Quotient are: ${ }^{61,73,74,75}$

1- Emotional Appeal: It refers to whether stakeholders have good feelings about the company, admire and respect the company, and trust the company. Emotion is the primary drive of reputation. Regarding ratings for other dimensions, each contributes to emotional appeal, which in turn creates reputation.

2- Products and Services: It refers to factors which measure the value that stakeholders perceive from the products and/or services, including high quality, innovation, and reliability, good value for money, strong brand, and stands behind products and/or services. 
3- Vision and Leadership: It denotes how stakeholders feel regarding the organizations' vision for the future and role/behavior of leaders such as a clear vision for the future, effective and excellent leadership, and capitalizing on market opportunities.

4- Workplace Environment: It refers to whether stakeholders believe the company is well managed, has a good workforce, and is a good place to work. Examples include good employees, good company to work for, appealing workplace, and talent.

5- Financial Performance: It includes factors which assess how stakeholders perceive the monetary strength of the company. Examples include a record of profitability, appearing to be worth to invest in, having strong prospects for future growth and tending to outperform competitors.

6- Social Responsibility: It measures factors which gauge the stakeholders' view of how the company complies with its responsibility to the environment and society in which it operates.

Examples include supporting good causes, citizenship, environmental stewardship, ethics, being environmentally responsible, and treating people well. Generally, the purpose of the RQ is to identify the foundation of a company's reputation, to benchmark that company against competitors and other comparison companies, and to identify the key cognitive attributes that drive corporate reputation. ${ }^{76}$

\section{The methodology}

Previous studies have revealed different outcomes and roles of a corporate reputation for Business to Consumer (B to C) companies from various perspectives, but few studies have identified them for Business to Business (B to B) companies. Furthermore, good reputation paves the organizational path to acceptance and approval by stakeholders. ${ }^{77}$ Examples of business to business companies are hotels and tour operators. Generally, hotels have been considered as the most important stakeholders (suppliers) for tour operators and travel agencies. This study deploys one of the newest approaches for measuring corporate reputation from the point of view of stakeholders. This approach is the Corporate Reputation Quotient (CRQ) which is based on surveying general population and aims to find out which companies are liked and respected by stakeholders, and for what reasons. However, to meet the objectives of the study, a conceptual model is built on the preceding literature review of Corporate Reputation Quotient; it is also devised to identify and highlight the points to be investigated and to guide the work through the field research.

\section{Research design}

The study adopts an exploratory survey to elicit attitudes and perceptions of stakeholders (hotels) towards ranking the most important factors of corporate reputation that drive the creation of tour operators' reputation. This kind of survey is best suited for describing population knowledge, beliefs, attitudes, preferences and behaviors. It is worth mentioning that similar studies have successfully used this survey design. ${ }^{\mathbf{7 8 , 7 9}}$ To achieve the objective of this paper, the researchers develop a model which was used later in constructing the questionnaire. Also, a set of general corporate reputation dimensions specific to the tourism industry have been identified based on the literature review of Corporate Reputation Quotient ${ }^{2,39,40,66,80}$ The completely worded individual items (statements) used to measure each factor are presented in Table (4) in order to explore the factors that determine the link between a tour operator's reputation and hotels' decisions regarding cooperation in services providing or supporting the operations of a company. In order to ensure that the research design is consistent with the research objectives, the methodology section has been executed in four stages, as follow:

\section{Creating the field study model}

To generate initial items, a review of the literature has been conducted in the broad contexts of Corporate Reputation Quotient. This step has been carried to determine the main factors of this approach. In the second step, the researchers tried to modify these factors to be relevant to tour operators' industry. Furthermore, a list of 6 Corporate Reputation factors has been screened out from the review of literature in the first step. These factors are: Emotional Appeal, Products and Services, Financial Performance, Vision and Leadership, Workplace Environment, and Social Responsibility. Through this above process, 31 initial items have been generated in attempting to cover Corporate Reputation attributes including 6 items supporting Emotional Appeal, 6 items for Products and Services, 4 items regarding Financial Performance, 5 items supporting Vision and Leadership, 5 items measuring Workplace Environment, and 5 items supporting Social Responsibility. This list of Corporate Reputation attributes was then sent to three identified groups for comments. The three identified groups were: academic staff, 5 hotel managers and 6 tour operators' managers. Therefore, after a careful screening analysis and advice from the three identified groups, 25 of the 31 attributes were selected to cover Corporate Reputation of tour operators (See Table 4) 


\section{Research instrument}

To analyze stakeholder's (hotels) perceptions to rank the tour operators' reputation factors, a specific questionnaire is designed since the suggested model has been transferred into self-administrated questionnaire. Furthermore, it is noted that the main advantage of conducting a self-administered questionnaire is that researchers can collect all of the completed responses within a short time. Through the questionnaire conducted in this way, any doubts that respondents may have on any question can be immediately clarified. Also, self-administering questionnaires to large numbers of individuals at the same time could be less expensive and save more time compared with an interview. Moreover, a self-administered questionnaire does not require as much skill to administer. ${ }^{81}$ Therefore, in order to obtain the required data, this questionnaire is made up of two sections: descriptive information associated with the stakeholder and corporate reputation 25 attributes, for which hotels were asked to indicate the perceived importance of the attributes when they choose a tour operator, sign contracts, or support the operation of the company.

The questionnaire has been structured so that each corporate reputation attribute is rated using a 5-point Likert scale, ranging from 1 (least important) to 5 (most important), in the attributes' part. Before conducting the main study, the researchers carried out a pilot study to establish whether the design of the questionnaire is sensible and the instrument is clear for respondents. Fifteen hotel managers pre-tested the questionnaire, and after receiving their comments, the questionnaire was then revised according to the comments received during the pilot study. The respondents found the personification metaphor approach easy to understand, and commented positively on the overall layout, instruction and design of the questionnaire. They also had no serious problem with clarity, and wording. However, a few items were reworded after the pilot exercise to improve the comprehensibility and clarity of the questionnaire instrument. The questionnaire's re-probe coefficient was equaled to 84.06. This constant verified the reliability of the questionnaire.

\section{The sampling method}

The sample chosen in this study includes five and four stars hotels in Egypt. The survey has been conducted in four significant tourist regions: Greater Cairo, South Sinai (Sharm-El-Sheikh), Red Sea (Hurghada and Marsa Alam), and Luxor provinces . These categories of hotels are chosen as stakeholders who are believed to be more knowledgeable and to have a basic understanding and acquaintance with these topics of research in order to obtain meaningful data. Moreover, these regions are chosen as they comprise a range of different hotel business types. Therefore, data is collected using the purposive sampling method, since the purposive sample is appropriate to be used with a criterion sample and provides indepth and rich data that the researcher is interested in. ${ }^{82}$ Then, the sample units are chosen randomly from the Egyptian Hotel Guide (33th edition, 2013-2014) which is produced by the Egyptian Federation of Tourist Chamber. Furthermore, the target population of this study is general managers, assistant general managers, operations managers, sales mangers or the decision-makers in hotels. Their responses would provide the information highly related with actual implementations and future plans.

The questionnaires were sent by mail then completed by telephone and sometimes by hand. The questionnaires were distributed from June 1 to August 25, 2014. The following table shows the number of distributed questionnaires and valid questionnaires:

Table (2) Elements of the Actual Sample

\begin{tabular}{|c|c|c|c|c|}
\hline Region & $\begin{array}{c}\text { No. of hotels included in } \\
\text { the sample }\end{array}$ & Distributed questionnaires & $\begin{array}{c}\text { Valid } \\
\text { questionnaires }\end{array}$ & $\%$ \\
\hline Greater Cairo & 21 & 58 & 49 & 84.4 \\
\hline Red Sea\& Marsa Alam & 32 & 68 & 59 & 86.7 \\
\hline Sharm El-Sheikh & 25 & 54 & 41 & 76 \\
\hline Luxor & 5 & 17 & 12 & 70.5 \\
\hline Total & 83 & 197 & 161 & 81.7 \\
\hline
\end{tabular}




\section{Data Analysis}

Data and information found in this study have been analyzed and discussed in accordance with the research objectives. The Statistic Package of the Social Sciences (SPSS v 17.0) is utilized to analyze the data obtained. In order to meet the research objectives of this study, all valid responses have been assessed using a variety of statistical techniques:

1. Descriptive statistics, including simple frequencies and mean ratings, have been computed.

2. Factor analysis is also used to determine the underlying factor structure that made up the sub-dimensions.

3. Reliability, in general, reliability is used to test the internal consistency among the variables or items through a summated scale. ${ }^{83}$ The most widely used test for internal consistency reliability is Cronbach's Coefficient Alpha ${ }^{84}$, which is used for multipoint-scaled items. Cronbach's Alpha is used to measure how well a set of items (or variables) measure a single uni-dimensional latent construct. Cronbach's Alpha is low when data have a multi-dimensional structure. Technically speaking, Cronbach's Alpha is a coefficient of reliability (or consistency), although it is not a statistical test. ${ }^{85}$

4. The Kruskal-Wallis test is used to test the median differences between groups; this test is similar to a one-way ANOVA test yet it is a non-parametric test based upon rank or ordinal data. This test was applied to compare the results based on the characteristics of the sample (hotels); the level of significance used was also $(\mathrm{P}<0.05)$.

\section{Results and Discussion}

\section{Sample Characteristics}

A total of 165 out of 197 managers completed the questionnaire in the survey period. 4 questionnaire forms were invalid. A total of 161 questionnaires were valid representing a response rate of $81.7 \%$. Furthermore, Table (3) illustrates the characteristics of the sample. The sample is divided into 49 hotels (30.4\% of total sample) located in Great Cairo, 59 hotels (36.6\% of total sample) were in the Red Sea and Marsa Alam, 41 hotels (25.4\% of total sample) were in Sharm-El-Sheikh, and only 12 hotels ( $7.4 \%$ of total sample) located in Luxor.

Table (3): Characteristics of the Sample (hotels)

\begin{tabular}{|l|l|l|}
\hline Variable & Frequency & Percent (\%) \\
\hline 1-Hotel's Location ( region): \\
\hline Greater Cairo & 49 & 30.4 \\
\hline Red Sea andMarsa Alam & 59 & 36.6 \\
\hline Sharm El-Sheikh & 41 & 25.4 \\
\hline Luxor & 12 & 7.4 \\
\hline 2-Hotel's Categories & 97 & 60.2 \\
\hline Five stars & 64 & 39.8 \\
\hline Four stars & \\
\hline 3-Labor Power & 40.9 \\
\hline Less than 500 employees & 66 & 32.2 \\
\hline 501-850 employees & 52 & 31.6 \\
\hline 851-1200 employees & 51 & 1.2 \\
\hline More than 1200 employees & 2 \\
\hline 4-Gross Revenue & \multicolumn{2}{|l|}{} \\
\hline Less than 30 million pounds & 29 & 18 \\
\hline 30-50 million pounds & 70 & 43.5 \\
\hline More than 50 million pounds & 62 & 38.5 \\
\hline 5-Respondents & 19.9 \\
\hline General Manger & 32 & 18.6 \\
\hline Assistant General Manager & 30 & 21.1 \\
\hline Operating Manager & 37 & 17.4 \\
\hline Sales Manager & 34 \\
\hline Decision Makers & 28 & \\
\hline 6-Carrying Studies about Tour Operators \\
\hline \multicolumn{2}{|l|}{} \\
\hline
\end{tabular}




\begin{tabular}{|l|l|l|}
\hline Always & 134 & 83.2 \\
\hline Sometimes & 12 & 7.5 \\
\hline Rarely & 15 & 9.3 \\
\hline
\end{tabular}

Results, as shown in Table (3), indicate that 97 hotels (60.2\% of the sample) are five stars hotels, while 64 hotels (39.8\% of the sample) are categorized as four stars hotels. The labor power of 66 hotels (40.9\% of the sample) is less than 500 employees while 52 of it (32.2\% of the sample) is within the range of 501-850 employees. $31.1 \%$ of the sample is within the range of 851-1200 employees. Only 2 hotels (1.2\% of the sample) employ more than 1200 employees. In addition, the highest percentage $(43.5 \%)$ of the respondent hotels reaps 30-50 million pounds as annual gross revenue. Also, the above results reveal that the majority of the sample (134 hotels with the percent of 83.2) always carry studies about tour operators before signing contracts. Only 12 hotels ( $7.5 \%$ of the sample) sometimes carry such studies. Also, 15 hotels (9.3\% of the sample) rarely have any procedure to sing contracts with tour operators.

\section{Assessment for Factor Analysis}

After the data was collected and tabulated, a series of statistical assumptions were tested to ensure the appropriateness of the data for factor analysis. Since, the data matrix was examined for sufficient correlations by computing the correlation matrix. It revealed that there were many substantial correlations above 0.30 , as suggested by researchers ${ }^{86}$ Thus, this indicated that the items shared common factors and were, therefore, suitable for factor analysis. Barlett's test of sphericity was conducted to examine whether the correlation matrix was different from an identity matrix $9 .{ }^{\mathbf{8 7 , 8 8}}$ In the correlation matrix for this study, the test value was large (23796.36) and the p-value was low (0.000), which implied that the data set was appropriate for factor analysis. Moreover, the Kaiser-Meyer-Olkin measure of sampling adequacy (MSA) was assessed. The MSA value was 0.878 . Therefore, the value is meritorious, which implies that the variables belong together and are appropriate for factor analysis. Table (4) shows the results of the factor analysis:

Table (4): Factor Analysis of Tour Operator Reputation Model (VARIMAX Rotation)

\begin{tabular}{|c|c|c|c|c|}
\hline Attributes & $\begin{array}{c}\text { Factor } \\
\text { Loading }\end{array}$ & $\underset{\mathbf{a}}{\mathbf{E V}}$ & $\begin{array}{c}\% \text { of } \\
\text { Variance }^{b}\end{array}$ & Communalities \\
\hline $\begin{array}{l}\text { 1-Emotional Appeal: } \\
\text { a- I have a good feeling about the tour operator } \\
\text { b-I respect the tour operator name } \\
\text { c-I trust this tour operator } \\
\text { d-This tour operator is attractive for potential employees }\end{array}$ & $\begin{array}{l}0.83 \\
0.72 \\
0.71 \\
0.71 \\
\end{array}$ & 10.8 & $27.02 \%$ & $\begin{array}{l}0.76 \\
0.68 \\
0.70 \\
0.71\end{array}$ \\
\hline $\begin{array}{l}\text { 2-Products and Services: } \\
\begin{array}{l}\text { a- } \quad \text { I think the tour operator Offers high-quality } \\
\text { products and services }\end{array} \\
\text { B- This tour operator Offers products and services that } \\
\text { are good value for money } \\
\text { c-The tour operator develops innovative products and } \\
\text { services } \\
\text { d- The tour operator has reliable products and services } \\
\text { e-Their products meet the expectations of customers }\end{array}$ & $\begin{array}{l}0.73 \\
0.91 \\
0.89 \\
0.70 \\
0.89\end{array}$ & 1.8 & 15.09 & $\begin{array}{l}0.65 \\
0.74 \\
0.52 \\
0.59 \\
0.63\end{array}$ \\
\hline $\begin{array}{l}\text { 3-Financial Performance: } \\
\text { a-I think the tour operator has a strong record of } \\
\text { profitability } \\
\text { b- The tour operator looks like a low-risk investment } \\
\text { c- The tour operator tends to outperform its competitors } \\
\text { d- It looks like a tour operator with strong prospects for } \\
\text { future growth }\end{array}$ & $\begin{array}{l}0.87 \\
0.85 \\
0.83 \\
0.93\end{array}$ & 3.2 & $9.8 \%$ & $\begin{array}{l}0.82 \\
0.79 \\
0.79 \\
0.50\end{array}$ \\
\hline $\begin{array}{l}\text { 4-Vision and Leadership: } \\
\text { a- } \quad \text { The tour operator has excellent leadership } \\
\text { b- } \\
\text { The tour operator has a clear vision for its } \\
\text { future } \\
\text { c-The company recognizes and takes advantage of } \\
\text { market opportunities } \\
\text { d-The tour operator has international expansion }\end{array}$ & $\begin{array}{l}0.87 \\
0.95 \\
0.88 \\
0.95\end{array}$ & 1.7 & $8.00 \%$ & $\begin{array}{l}0.58 \\
0.65 \\
0.61 \\
0.63\end{array}$ \\
\hline
\end{tabular}




\begin{tabular}{|c|c|c|c|c|}
\hline $\begin{array}{c}\text { 5-Workplace Environment: } \\
\text { a-I believe the tour operator is well-managed } \\
\text { b-The tour operator looks like a good company to work } \\
\text { for } \\
\text { c-The tour operator looks like a company that would } \\
\text { have good employees }\end{array}$ & $\begin{array}{l}0.91 \\
0.87 \\
0.90\end{array}$ & 1.2 & $6.76 \%$ & $\begin{array}{l}0.79 \\
0.78 \\
0.77\end{array}$ \\
\hline $\begin{array}{c}\text { 6-Social Responsibility: } \\
\text { a-The tour operator is an environmentally responsible } \\
\text { company } \\
\text { b-The tour operator maintains a high standard in the } \\
\text { way it treats people } \\
\text { c- The tour operator seems as a good citizen in its } \\
\text { dealings with communities } \\
\text { d- The tour operator seems as a good citizen in its } \\
\text { dealings with employees } \\
\text { e-The tour operator has high transparency }\end{array}$ & $\begin{array}{l}0.75 \\
0.83 \\
0.70 \\
0.89 \\
0.77\end{array}$ & 10.6 & $22.56 \%$ & $\begin{array}{l}0.69 \\
0.27 \\
0.48 \\
0.77 \\
0.68\end{array}$ \\
\hline
\end{tabular}

Corporate reputation attributes were factor-analyzed, using principal component analysis with orthogonal VARIMAX rotation, to identify the underlying dimensions or factors. The exploratory factor analysis was conducted in order to gain a better understanding of the underlying structure of the data. The results of the factor analysis included 25 corporate reputation attributes, and explained $66.67 \%$ of the variance in the data with eigenvalues greater than 1.0. Also, as shown in Table(4), the factor loadings of each item exceeded 0.5, and so met the threshold level recommended by Bagozzi and $\mathrm{Yi}^{{ }^{89}}$ Moreover, the convergent validity of each scale's item is satisfying 0.50 . Therefore, the factor analysis in this study proved to be acceptably valid with communalities ranged from 0.48 to 0.82 with an average value 0.65 , suggesting that the variance of the original values was fairly explained by the common factors. As mentioned above, reliability analysis (Cronbach's Alpha) was conducted to test the reliability and internal consistency of each factor. The results showed that the Alpha coefficients of the six factors ranged from 0.80 to 0.88 . It is above the minimum value of 0.50 ; therefore, it is considered acceptable as an indication of reliability for basic research.

Table (5) Mean Rating and Ranking Importance of Tour Operator Reputation Factors

\begin{tabular}{|c|c|c|c|}
\hline Attributes & Mean & $\begin{array}{l}\text { Std. } \\
\text { Dev }\end{array}$ & Rank \\
\hline 1-Emotional Appeal: & 2.7 & .48 & 6 \\
\hline a- I have a good feeling about the tour operator & 2.2 & .92 & \\
\hline b- I respect the tour operator name & 3.4 & .91 & \\
\hline c- I trust this tour operator & 3.4 & .95 & \\
\hline d- This tour operator is attractive for potential employees & 1.8 & .78 & \\
\hline 2-Products and Services: & 3.0 & .59 & 4 \\
\hline a- I think the tour operator offers high-quality products and services & 3.2 & 1.07 & \\
\hline $\begin{array}{c}\text { b- This tour operator Offers products and services that are good } \\
\text { value for money }\end{array}$ & 2.8 & 1.02 & \\
\hline c- The tour operator develops innovative products and services & 2.9 & 1.07 & \\
\hline d- The tour operator has reliable products and services & 3.1 & 1.10 & \\
\hline
\end{tabular}




\begin{tabular}{|c|c|c|c|}
\hline e- Their products meet the expectations of customers & 2.9 & .99 & \\
\hline 3-Financial Performance: & 3.8 & .44 & $\mathbf{1}$ \\
\hline a- I think the tour operator has a strong record of profitability & 4.3 & .73 & \\
\hline b- The tour operator looks like a low-risk investment & 3.5 & .86 & \\
\hline c- The tour operator tends to outperform its competitors & 3.4 & .90 & \\
\hline $\begin{array}{l}\text { d- It looks like a tour operator with strong prospects for future } \\
\text { growth }\end{array}$ & 4.1 & .79 & \\
\hline 4-Vision\&Leadership: & 3.4 & .50 & 2 \\
\hline a- The tour operator has excellent leadership & 3.3 & .79 & \\
\hline b- The tour operator has a clear vision for its future & 2.9 & 1.06 & \\
\hline $\begin{array}{c}\text { c- The tour operator recognizes and takes advantage of market } \\
\text { opportunities }\end{array}$ & 3.3 & 1.0 & \\
\hline d- The tour operator has international expansion & 4.2 & .79 & \\
\hline 5-Workplace Environment: & 3.2 & .65 & 3 \\
\hline a- I believe the tour operator is well-managed & 3.6 & .88 & \\
\hline b- The tour operator looks like a good company to work for & 3.1 & .88 & \\
\hline $\begin{array}{c}\text { c- The tour operator Looks like a company that would have good } \\
\text { employees }\end{array}$ & 2.4 . & .83 & \\
\hline 6-Social Responsibility: & 2.8 & .32 & 5 \\
\hline a- The tour operator is an environmentally responsible company & 2.6 & .84 & \\
\hline $\begin{array}{c}\text { b- The tour operator maintains a high standard in the way it treats } \\
\text { people }\end{array}$ & 2.5 & .85 & \\
\hline $\begin{array}{l}\text { c- The tour operator seems as a good citizen in its dealings with } \\
\text { communities }\end{array}$ & 2.6 & .88 & \\
\hline $\begin{array}{c}\text { d- The tour operator seems as a good citizen in its dealings with } \\
\text { Employees }\end{array}$ & 2.6 & .65 & \\
\hline e- The tour operator has high transparency & 3.7 & .64 & \\
\hline
\end{tabular}

As mentioned above, in order to measure hotels' perception as a stakeholder, six corporate reputation dimensions have been selected; these dimensions are selected according to Corporate Reputation Quotient. According to Table (5), the mean scores on each attribute of tour operator reputation are 2.7 for Emotional Appeal, 3.0 for Products and Services, 3.8 for Financial Performance, 3.4 for Vision and Leadership, 3.2 for Workplace Environment, and 2.8 for Social Responsibility. These results shed light on the main areas of tour operator reputation that stakeholders concentrate on. Furthermore, when ranking the pushing motivators of stakeholders to highly evaluate the tour operator reputation, the most important factors with the highest mean scores are "Financial Performance" and "Vision and Leadership".

Moreover, these results confirm the study of Melewar, ${ }^{53}$ Roberts and Dowling ${ }^{90}$ who found that financial performance and strong leadership have significant and positive association with corporate reputation. Since they explained that investors, for example, purchase stocks or financial securities based on the current and historical earnings of companies, and they generally favor companies with better and more stable incomes. Thus, it can be concluded that accounting performance (represented by the return on invested capital ratio) has been found to be positively correlated with the reputation of companies across industries. ${ }^{47}$ 
On the contrary, the factors "Emotional Appeal" and "Social Responsibility" are ranked as the least important. Also, these results confirm the study of Hutton et al. ${ }^{91}$ who concluded that there is no relationship between reputation and spending on corporate communication activities. However, the results of this study do not match with the findings suggested by Yang and Peterson who concluded that loyalty can be generated through offering high product/service value ${ }^{\mathbf{9 2}}$, and the results of the study by Davies et al. ${ }^{\mathbf{3}}$ who found that the quality of product and service is classified as a component of firms' core values which shapes reputation. This conclusion may be explained with regard to the association between corporate reputation and product and service quality which may not be simple and direct; for example, the relationship between product and service quality and corporate reputation can be mediated by customer satisfaction. ${ }^{\mathbf{9 4}}$ High product and service quality is an important determinant of corporate reputation but it is not sufficient alone for effective reputation building.

The results also do not match with the study of Fombrun ${ }^{\mathbf{3 3}}$ and the study of Dowling ${ }^{\mathbf{9 5}}$ who argue that reputation is mainly built in a planned manner by organizations taking necessary notice of the environment in which they operate. They should concern for the development of local communities; and that ensure the quality and environmental soundness of their technologies, products and services. ${ }^{\mathbf{2 9}, 77}$ However, with regard to the respondents there is a significant and positive link between corporate social responsibility and tour operator reputation. Also, the results in Table (5) indicate that work place is another key driver of company reputation and significantly influences stakeholders, but only with rating mean of 3.2.

\section{The Kruskal-Wallis test}

The data presented in Table (6) shows that there is significant difference between hotels' categories (four or five stars) in their perception of the corporate reputation factors importance with respect only to the "Products \&Services", "Vision and Leadership", and "Workplace Environment". Moreover, it is noticed that five stars hotels are more concerned by these attributes during measuring the tour operator reputation. On the other hand, the different hotel categories have the same direction with respect to the factors "Emotional Appeal", "Financial Performance", and" Social Responsibility".

Table (6): Testing Equality of Variable Mean Regarding Hotels' Category (Kruskal-Wallis)

\begin{tabular}{|l|c|c|}
\hline \multicolumn{1}{|c|}{ Factors (variable) } & Value of Kruskal-Wallis Test & Sig \\
\hline 1- Emotional Appeal & 1.780 & .180 \\
\hline 2- Products and Services & 58.326 & .000 \\
\hline 3- Financial Performance & 2.359 & .125 \\
\hline 4- Vision and Leadership & 37.063 & .000 \\
\hline 5- Workplace Environment & 11.747 & .001 \\
\hline 6- Social Responsibility & 2.471 & .166 \\
\hline
\end{tabular}

Table (7): Testing Equality of Variable Mean Regarding Hotels' Location (Region) (Kruskal-Wallis)

\begin{tabular}{|l|c|c|}
\hline \multicolumn{1}{|c|}{ Factors (variable) } & Value of Kruskal-Wallis Test & Sig \\
\hline 1- Emotional Appeal & 8.119 & .044 \\
\hline 2- Products and Services & 7.763 & .051 \\
\hline 3- Financial Performance & 7.740 & .052 \\
\hline 4- Vision and Leadership & 14.220 & .003 \\
\hline 5- Workplace Environment & 11.298 & .010 \\
\hline 6- Social Responsibility & 11.180 & .011 \\
\hline
\end{tabular}

The data analyzed in the above table shows that there is no significant difference between hotels' perception of the corporate reputation factors importance in different places (governorates) with respect to the "Emotional Appeal", "Products and Services", "Financial Performance", "Workplace Environment", and "Social Responsibility" factors. However, there is a significant difference in ranking "Vision and Leadership" as a reputation factor. This result may be due to the different conditions affecting the business in different geographical locations, which generally affect the investment climate.

Table (8): Testing Equality of Variable Mean Regarding Hotels' Gross Revenue (Kruskal-Wallis)

\begin{tabular}{|l|c|c|}
\hline \multicolumn{1}{|c|}{ Factors (variable) } & Value of Kruskal-Wallis Test & Sig \\
\hline 1- Emotional Appeal & 1.156 & .561 \\
\hline 2- Products and Services & 23.407 & .000 \\
\hline 3- Financial Performance & 3.004 & .223 \\
\hline 4- Vision and Leadership & 28.291 & .000 \\
\hline 5- Workplace Environment & 4.784 & .091 \\
\hline 6- Social Responsibility & 4.032 & .133 \\
\hline
\end{tabular}


The previous table presents further data analysis to show whether the obtained results are restricted to a particular hotels' gross revenue or not. Surprisingly, The Kruskal-Wallis analysis indicates that there is a significant difference between hotels' gross revenue with respect only to the "Products and Services" and "Vision and Leadership" factors of tour operator reputation. This result may return to stakeholders (with high gross revenue) who usually purchase services from winning firms because it is more likely that successful companies can continuously provide high-quality services and products and always be there to satisfy any guarantees made.

Table (9): Testing Equality of Variable Mean Regarding Carrying Studies (Kruskal-Wallis)

\begin{tabular}{|l|c|c|}
\hline \multicolumn{1}{|c|}{ Factors (variable) } & Value of Kruskal-Wallis Test & Sig \\
\hline 1- Emotional Appeal & .229 & .861 \\
\hline 2- Products and Services & .290 & .865 \\
\hline 3- Financial Performance & & .038 \\
\hline 4- Vision and Leadership & 6.566 & .266 \\
\hline 5- Workplace Environment & 2.650 & .443 \\
\hline 6- Social Responsibility & 2.629 & .355 \\
\hline
\end{tabular}

The results in Table (9) clearly state that The Kruskal-Wallis analysis indicates the absence of any significant difference between carrying studies about tour operators before signing any contract with respect to the six factors of the tour operator reputation. This result indicates that the entire hotels' sample built its vision in advance.

\section{Conclusion and implications}

Corporate reputation is vitally important. Moreover, the importance of corporate reputation as one of intangible assets has grown rapidly within the last two decades. The companies with the best reputations are those who have close and interactive relationships with their stakeholders. They also have policies and practices that offer ongoing and mutual benefit to these stakeholders, who include employees, customers, shareholders, regulators and suppliers. Despite the apparent importance of corporate reputation, it is still imperfectly understood as to how corporate reputation is built and maintained especially in the tourism industry. Furthermore, corporate reputation is a long-term judgment and evaluation of a firm by its stakeholders. It implies the long-lasting, collective assessment rendered over a long period of time. Also, judgment, evaluation, and assessment by stakeholders include the emotional appeal of a firm, the range of products and services offered, the vision of its leadership, the workplace environment in the firm, the social and environmental responsibility of the firm, and its financial performance. The purpose of this study is to explore the most important factors that determine the link between tour operators' corporate reputation and stakeholders' decisions of cooperation in service production or supporting the operations of a company. In order to achieve the objectives of the study, the researchers follow the Corporate Reputation Quotient approach which was developed by the Reputation Institute jointly with Harris Interactive in 1999. Moreover, a number of hotels' managers were asked to identify the most important factors that drive the creation of the tour operators' corporate reputation. The findings of this study have generated important insights into the way stakeholders evaluate corporate reputation's factors. Hotels as suppliers are ranking the pushing motivators of stakeholders to highly evaluate the tour operator reputation. The results of the present study suggest that for corporate reputation the "Financial Performance" factor leads to a more favorable reputation. Also, concentrating on the "Vision and Leadership" factor can result in a positive perception of the company. On the other hand, the "Emotional Appeal" and "Social Responsibility" factors do not increase the diagnostic value of the corporate reputation; stakeholders might reason that if a company is trustworthy in its financial, it is likely to be trustworthy in other respects as well. These results send a meaningful message to tour operators; they should concentrate on these aspects from their stakeholders' point of views. Tour operators should pay more attention to improving and maintaining their reputation by mainly developing their "Financial Performance" and "Vision and Leadership" ability. They also should do moderated efforts to present their products or services and workplace environment to suppliers. However, there is no serious need to show their efforts in "Social Responsibility" or create "Emotional Appeal" to build a high reputation.

The results also show that there is significant difference between hotels' categories (four or five stars) in their perception of the importance of the corporate reputation factors with respect only to the "Products and Services", "Vision and Leadership", and "Workplace Environment". Furthermore, there is a significant difference between hotels' gross revenue with respect only to the factors "Products and Services" and "Vision and Leadership" of tour operator reputation. Overall, this study has yielded some interesting findings. However, further research needs to be conducted to gain a better understanding, taking into consideration enlarging the sample size, as the technique used in the current study is restricted by reputation factors. Also, it is valuable to choose other tourist destinations, using another approach of measuring corporate reputation and another type of stakeholders; this is recommended in order to have a more comprehensive view. Besides, it would be useful to carry out further studies to provide additional insights into the development, management and benefits of corporate reputation. 


\section{Reference}

(1) Inglis, R.; Morley, C. and Sammut, P. (2006) Corporate reputation and organizational performance: An Australian study. Managerial Auditing journal , 21(9), 934-947.

(2) Marchiori, E., Inversini, A., Cantoni, L. and Dedekind, C. (2010) Towards a Tourism Destination Reputation Model. A first step. In Proceedings of the 6th International Conference "Thought Leaders in Brand Management", (Lugano, Switzerland, 18-20 April 2010), Available ht: www.academia.edu/2482695/Towards_a_tourism_destination_reputation [Accessed on 12 March 2014].

(3) Driel , C. (2002) Towards a profitable RQ for governmental and not- for- profit organization , Available at : http:/ www.docstoc.com/.../Towards-a-profitable...for Governmental-and-Not-for [Accessed on 12 March 2014].

(4) Griffin, A.( 2008 ) New Strategies For Reputation Management : Gaining Control of Issues, Crises \& Corporate Social Responsibility , Kogan Page, London.

(5) Michelotti, P. (2008)An analysis of the determinants of corporate reputation and stakeholder decisions to purchase, work, invest and support community operations, Working paper, Swinburne University of Technology, Available at: http/www. papers.ssrn.com/sol3/papers.cfm?abstract_id=1150697[Accessed on 18 April 2014].

(6) Saulen, J.A. (2011) Reputation Management: A Qualitative Analysis of the Effective Use of Reputation Management Techniques Applied to Personal Reputations during a Crisis, Master of Science in Journalism, Morgantown, West Virginia.

(7) Forstmose , P. and Herger, N. (2006) Managing Reputational Risk: A Reinsurer's View , Palgrave Macmillan Journals, The Geneva Papers on Risk and Insurance - Issues and Practice,

Special Issue on Reputational Risk ,31( 3), 409-424.

(8) Gray, E.R. and Balmer, J.M.T. (1998) Managing corporate image and corporate reputation. Long Range Planning, 31 (5), 695-702.

(9) Shamma, H. M. (2012) Toward a Comprehensive Understanding of Corporate Reputation: Concept, Measurement and Implications. International Journal of Business and Management, 7(16), 151- 169.

(10) Sims, R. (2009) Toward a Better Understanding of Organizational Efforts to Rebuild Reputation following an Ethical Scandal . Journal of Business Ethics, 90(4), 453-472.

(11) Miller , B.M. (2003) Reputation Management: A Qualitative \& Quantitative Analysis Of The Effective Use Of Reputation Management Techniques When Faced With Crisis Situations Including The Construction And Validation Of A Media Index For Framing Tones In Crisis Situations, Master of Science in Journalism, Morgantown, West Virginia.

(12) Srivatsa, M. and Liu, L. (2006) Securing decentralized reputation management using Trust Guard. Journal of Parallel and distributed computing, $66,1217-1232$.

(13) Awang , Z. (2010) Analyzing the Effects of Corporate Reputation on the Competitiveness of Telecommunication Industry using the Structural Equation Modeling: The Case of Kelantan, Proceedings of the Regional Conference on Statistical Sciences 2010 (RCSS'10) June 2010, 283-296. Available at: http/ www.academia.edu/1585850/Analyzing_the_Effects_of_Corporate... [Accessed on 12 March 2014].

(14) Ozturk, Y. , Cop, S. and Sani, R. (2010) The Effect Of Corporate Reputation Management As A Competition Tool On Tourism Businesses, Available at: http://digitalscholarship.unlv.edu/hhrc/2010/june2010/3/ [Accessed on 27May 2014].

(15) Inversini, A., Marchiori, E., Dedekind, C. and Cantoni, L.(2010) Applying a Conceptual Framework to Analyze Online Reputation of Tourism Destinations. In Gretzel, U., Law, R. and Fuchs,M. (Eds.), Information and Communication Technologies in Tourism 2010 - Proceedings of the International Conference in Lugano, Switzerland, Wien: Springer, pp. 321-332.

(16) Horster,E. and Gottschalk, C. (2012) Computer-assisted Webnography: A new approach to online reputation management in tourism. Journal of Vacation Marketing,18(3),229-238.

(17) Mak, A.K( 2005 ) Identity-Centered Model of Reputation Management: A Case Study of Iowa Tourism Office and its Industry Partners, In Proceedings of the 8th International Public Relations Research Conference " The Impact of PR in Creating a More Ethical World: Why Can't We All Get Along?", Best Western South Miami , Florida, 10 13March , 2005, pp. 270-291.

(18) Schultz, H.B. and Werner, A. Reputation Management. Available at: http://www.oxford.co.za/download_files/cws/Reputation.pdf,[Accessed on 30July 2014].

(19) Jankovicz, K. (2010) A Reputation of Responsibility In A Controversial Industry: How To Make It Happen , Bachelor of Arts in Marketing and Management Communication, Aarhus University.

(20) Horster, E.( 2011) The Influence of Travel Company Reputation on Online Travel Decisions . e-Review of Tourism Research,9(3),107-113.

( 21 ) Zhang, Y( 2009) A Study of Corporate Reputation's Influence on Customer Loyalty Based on PLS-SEM Model. International Business Research, 2 (3) , 28- 35. 
(22) Schreiber, E.S. (2006) Reputation \& Brand Management: The Role of Corporate Communications in Building and Retaining Value: Public Relations Leadership Forum Available at: http/ www,fr.slideshare.net/Ramen24/elliot-sschreiber-phd/ / [Accessed on 18April 2014].

(23) Cherchiello, R. (2011) Statistical Models to Measure Corporate Reputation, The International Conference "Innovation and Society 2011. Statistical Methods for the Evaluation of Services (IES 2011)". Journal of Applied Quantitative Methods, 6(4),58-71.

(24) Falkenreck,C. (2010) Reputation transfer to Enter New B-To-B Markets : Measuring and Modelling Approaches, Springer-Verlag Berlin Heidelberg . www.ebooks-share.net/reputation-transfer-to-enter-new-b-to-b. [Accessed on 30July 2014].

(25) Pratoom, K. (2010) Validating the Reputation Quotient Scale: Human Resource Management Perspective. International Business Management journal, 4(4), 243-249.

(26) Reino,S., Serna,A., Lamsfus,C. and Sorzabal, A. (2012) A New Hotel Online Reputation Framework for Ontology Learning Development ; In proceeding of: ENTER2012, E-Tourism Present and Future Services and Applications.

(27) Christelis, D. (2006) Country Reputation Management: Identifying the drivers of South Africa's reputation in German media , the degree of Master, University of Stellenbosch.

(28) Hillenbrand, C. and Money, K. (2009) Segmenting stakeholders in terms of Corporate Responsibility: Implications for Reputation Management. Australasian Marketing Journal,17, 99-105.

(29) Remondino, M. and Boella G. (2010) How users' participation affects reputation management systems: The case of P2P networks . Simulation Modelling Practice and Theory, 18, 1493-1505.

(30) Wæraas, A. and Sataøen, H. L. (2013) Trapped in conformity? Translating reputation management into practice. Scandinavian Journal of Management, Article in press.

(31) Fiedler, L.(2011) Reputation Management in Different Stakeholder, In Helm, S. , Gobbers, K. L. and Storck, C. (eds.), Reputation Management, Management for Professionals, Springer-Verlag Berlin Heidelberg ,pp. 127- 149.

(32) Péreztrejo, L. R. (1991) The Importance Of Corporate Reputation Of A Mexican Packaging Producer In Building Customer Retention, Available at: http/ www Primera Revista Electrónica en América Latina Especializada en Comunicación citeseerx.ist.psu.edu/showciting?cid=829707[Accessed on 18April 2014].

(33) Fombrun, C. J. (1996) Reputation: Realizing value from the corporate image. Boston: Harvard Business School Press.

(34) Bishop, G.A. (2001) Corporate Reputation Management: A Method For Creating Proactive, Adaptive Organizations, the degree of Master Of Arts In Leadership And Training, Royal Roads University, Canada .

(35) KIM, J. (2010) The link between service quality, corporate reputation and customer responses, Degree of Doctor of Philosophy in the Faculty of Humanities, University of Manchester.

(36) Harrison, K. (2011) Why a good corporate reputation is important to your organization available at :http://www.cuttingedgepr.com/articles/corprep_important.asp the communicationsguru.blogspot.com/...corporatereputation-is.html. [Accessed on 18April 2014].

(37) Park, J ., Lyon, L. and Cameron, G. T. ( 2000 ) Does Reputation Management Reap Rewards? A Path Analysis of Corporate Reputation Advertising's Impacts on Brand Attitudes and Purchase Decisions. The Web Journal of Mass Communication Research, 4(1).

(38) Christopher, B., Robin, C. and Emilia, K.(2008)How graduating students perceive the staffing and recruitment industry - A study on corporate reputation, Bachelor Thesis within Business Administration, Jonkoping International Business School, Jonkoping University.

(39) Wun, F. and Hung, C.(2002) Reputation Quotients: The Evaluation of Corporate Reputation in Hong Kong , The International Communication Association, Dresden International Congress Centre, Dresden, Germany, Available at http://citation.allacademic.com/meta/p_mla_apa_research_citation/0/9/3/0/6/pages/p93062-44... [Accessed on 30July 2014].

(40) McCutchen,P. (2005) How's Your Company "RQ" (Reputation Quotient)? Available at: http:/ www.ezinearticles.com/?Hows-Your-Company-RQ)-Reputation-Quotient\&?(id...=[ Accessed on 18 April 2014]

(41) Fombrun, C.J. and Van Riel, C.B.M. (2003) Company Reputations: Who's Tops-and Who's Not? In Fame and Fortune: How Successful Companies Build Winning Reputations, FT Prentice Hall, 1 edition. ButterworthHeinemann, Oxford, UK. , Available at: www.ftpress.com/articles/article.aspx?p=101397. [ Accessed on 30July 2014]

(42) Apéria ,T., Brønn , P.S. and Schultz, M. (2004 ) A Reputation Analysis of the Most Visible Companies in the Scandinavian Countries. Corporate Reputation Review, 7(3), 218-230.

(43) Ishihara, K. (2006) Reputation Management in the Japanese Insurance Marketplace, Palgrave Macmillan Journals, The Geneva Papers on Risk and Insurance - Issues and Practice

Special Issue on Reputational Risk, 31( 3), 446-453.

(44) Martin, G. and Hetrick, S.(2006) Corporate Reputations, Branding and People Management, A Strategic Approach to HR , Elsevier Butterworth-Heinemann. 
(45)Abraham, S.E. ,Friedman, B. A. ,Khan, R.H. and Skolnik, R.J. (2008) Is Publication of the Reputation Quotient (RQ) Sufficient to Move Stock Prices?. Corporate Reputation Review, 11, 308-319.

(46) Sheehan, N.T. and Stabell, C.B. (2010) Reputation as a Driver in Activity Level Analysis: Reputation and Competitive Advantage in Knowledge Intensive Firms. Corporate Reputation Review, 13, 198-208.

(47) Frombrun,C. and Shanley, M. (1990) What's in a Name? Reputation Building and Corporate Strategy. Academy of Management Journal , 33(2), 233-258.

(48) Keh, H.T. and Xie , Y. (2009) Corporate reputation and customer behavioral intentions: The roles of trust, identification and commitment. Industrial Marketing Management ,38, 732-742.

(49) Tuck , J. (2007) Stakeholder Priorities v Industry Perception: Reputations and Relationships in the Australian Mining Industry, PAPER: 11th International Conference on Reputation, Brand, Identity \& Competitiveness, 31 May - 3 June, Oslo, Norway .

(50) Cravens , K.S. and Oliver, E.G. (2006) Employees: The key link to corporate reputation management. Business Horizons, 49, 293-302.

(51) Greyser, S.A. (1999) Advancing and enhancing corporate reputation . Corporate Communications: An International Journal, 4(4),177-181.

(52) Dalton, J. and Croft , S. (2003) Managing Corporate Reputation, Thorogood, London ,p p. 11-14.

(53) Melewar ,T. (2008) Facets of Corporate Identity, Communication, and Reputation, Routledge Taylor \& Francis Group, New York, p. 143.

(54) Freeman, R.E., Harrison, J.S. and Wicks, A.C.(2007) Managing for Stakeholders : Survival,Reputation, and success, Yale University Press, New Haven \& London.

(55) Vijayanand, S. (2014) Stakeholders and public private partnerships role in tourism management, Available at: http://www.ijser.org/researchpaper\%255CStakeholders-and-public-private-partnerships-role-in...\& http://www.academia.edu/1957079/Stakeholders_and_public_private_partnerships_role_in_touris. [Accessed on 30July 2014].

(56) Gobbers, K.L. and Storck, C.(2011) Reputation Management, In Helm, S. , Gobbers,K. L. and Storck, C. (eds.), Reputation Management, Management for Professionals, Springer-Verlag Berlin Heidelberg, 17-20.

(57) Kokemuller, N. (2014) Who are the External Stakeholders of a Company? , Available at: http://smallbusiness.chron.com/external-stakeholders-company-64041.html [ Accessed on 30July 2014]

( 58 ) Munoz, D. ; Falcon ,J. and Munoz, R. (2002) Building the Valuable Connection Hotels and Travel Agents, Cornell university . Cornell Hotel and Restaurant Administration Quarterly 43(3), 46-52.

(59) Dimitrios , B. (2000) Relationships in the distribution channel of tourism: conflicts between hoteliers and tour operators in the Mediterranean Region, International journal Hospitality and Tourism Administration, 1(1), 113-139

(60) Schwaiger, M.(2004) Components And Parameters Of corporate reputation - AN Empirical Study. Schmalenbach Business Review, 56, $46-71$.

(61) Balkema, L. (2012) The public and its television: A reputational study of BBC One, Master of Science degree in Marketing and International Business, University of Iceland.

(62) Serbanica, C. and Popescu, T.(2009) The Perception Over Country Reputation, A Picture Of The Country Profile. A Romanian Case Study. Vilnius law and business college, Current Issues Of Business And Law, 3, 47-65.

(63) Kanto,D. S. , Run, E.C. and Md Isa , A.H. (2013) Developing an Alternative Measurement of Corporate Reputation within the Malaysian Context . Interdisciplinary Journal of Contemporary Research In Business ,5(1), 730-738.

(64) Botha, E. S. ,Sanders, A. and Viljoen, O.( 2009) Corporate Reputation and Service Firms: Which Elements Impact Consumer Choice? The Impact of Corporate Reputation on Learners' Choice of University, Available at : http:// www.duplication.net.au/ANZMAC09/Papers.html[Accessed on 25March2014].

(65) Sala, M.C. (2011) Creating a New Multistakeholder Methodology for Measuring Corporate Reputation, Degree of Doctor of Philosophy, Pompeu Fabra University, Barcelona.

(66) Horn, R. (2013) Is the Reputation Quotient a valid and reliable measure for corporate reputation? Master thesis in Business Studies ,Universität Kassel , Germany.

(67) Caruana, A. (2008) An attitudinal measure of corporate reputation, In Facets of Corporate Identity, Communication, and Reputation. Melewar, T.C. (Eds.), Routledge Taylor \& Francis Groups, New York, p. 197.

(68) Trotta , A. and Cavallaro , G. (2012) Measuring Corporate Reputation: A Framework For Italian Banks . International Journal of Economics And Finance Studies,4(2), 21-30.

(69) Dörr , R. (2012) A Framework for measuring Corporate Reputation changecom.wordpress.com/2012/10/23/aframework-for-measuring...[Accessed on 25March2014].

(70) Rayner, J. (2003 ) Managing Reputational Risk, John Wiley \& Sons Ltd, England.

(71) Moleleki, M.A. (2011) How the behavior of corporate leaders affects corporate reputation,

Master in Business Administration, North-West University. 
(72) Tjandra, R. ( 2013) Corporate Reputation as Comparative Advantage , Available at : http:/ www. rudolftjandra.com/corporate-reputation-as-comparative-advantage[Accessed on31March2014].

(73) Men, L.R. (2010) Measuring the Impact of Leadership Style and Employee Empowerment on Perceived Organizational Reputation, Degree of Doctor of Philosophy, School of Communication, University of Miami.

(74) Broman, C., Cabander, R. and Karlsson, E. (2008) How graduating students perceive the staffing and recruitment industry - A study on corporate reputation, Bachelor Thesis within Business Administration , Jönköping International Business School, Jönköping University.

(75) Fombrun ,C.J. and Foss, C. B. (2001) The Reputation Quotient, Developing a Reputation Quotient, 14(3) , Available at: http/ www reputation institute.com/frames/press/01_15_14_GUAGE.pdf · PDF[ Accessed on 03 April 2014].

(76) Reputation institute ( 2000) The Euro-RQ: A Multi-Country Study of Corporate Reputation Available at: http://www corporate3.com/t/the-euro-rq-a-multi-country-study-of-corporate.[ Accessed on 03 April 2014].

(77)Watson ,T., and Kitchen ,P (2010) Reputation management: Corporate Image and Communication. available at:http www www eprints.bournemouth.ac.uk/12633/2/Chapter_13_def.pdf,[ Accessed on 03 April 2014].

(78) Cheruiyot ,T. ; Maru, C. and Muganda ,C.(2012) Reconstructing Dimensionality of Customer Corporate Social Responsibility and Customer Response Outcomes by Hotels in Kenya . Journal of business, Economics and Finance , $1(3)$.

(79) Leone,R. and Rao,V. (2006) Linking Brand Equity to Customer Equity. Journal of Service Research, 9(2), 125-138.

(80) Fombrun, C. J.; Gardberg, N. A. and Server, J. M. (2000) The reputation quotient: a multi-stake holder measure of corporate reputation. Journal of Brand Management, 7(4), 4-13.

(81) Sekaran, U. (2003) Research methods for business: A skill building approach ,4th ed., New York, NY, John Wiley \& Sons.

(82) Lisa M., G. (2008) The Sage Encyclopedia of Qualitative Research Methods. Sage: Thousand Oaks, CA, 2,pp. 697698.

(83) Hair, J. F., Black, W. C., Babin, B. J., Anderson, R. E., and Tatham, R. L. (2006) Multivariate data analysis ,6th ed. Upper Saddle River, NJ. Prentice-Hall.

(84) Cronbach, L. J. (1946) Response sets and test validating. Educational and Psychological Measurement, 6, $475-494$.

(85) UCLA Academic Technology Services. (2007) What does Cronbach's alpha mean? Available at: http://www.ats.ucla.edu/stat/Spss/faq/alpha.html[ Accessed on 12Augst 2014]

(86) Hair, J. F., Anderson, R. E., Tatham, R. L. and Black, W. C. (1998) Multivariate data analysis ,5th ed. Upper Saddle River, NJ, Prentice-Hall

(87) Lai, C. S., Lo, H. W. A., and Shieh, V. (2007) Integrated medical education: Development and implementation of a humanistic pedagogy at Kaohsiung Medical University. Available at:

http://www.ehumed.kmu.edu.tw/images/papers/Action\%20studies/Integrative\%20Medical \%20Education.pdf.[ Accessed on 16 April 2014].

(88) Fischman, E. I.; Shinholser, K. J., and Powers, J. J. (1987) Examining methods to test factor patterns for concordance. Journal of Food Science, 52(2), 448-450.

(89) Bagozzi, R. P., Yi, Y., and Baumgartner, J. (1990) The level of effort required for behavior as a moderator of the attitude-behavior relation. European Journal of Social Psychology, 20(1), 45-59

(90) Roberts, P. and Dowling, G. (2002) Corporate reputation and sustained superior financial performance. Strategic Management Journal, 23(12), 1077-93.

(91) Hutton, J. G., Goodman, M. B. ; Alexander, J. B. and Genest C. M. (2001) Reputation management: The new face of corporate public relations. Public Relations Review, 247, 249.

(92) Yang , Z and Peterson, R.(2004 ) Customer Perceived Value, Satisfaction, and Loyalty: The Role of Switching Costs, Psychology and Marketing, 21(10),799-822

(93) Davies, G., Chun, R., Silva, R., and Roper, S. (2003) Corporate Reputation and Competitiveness. Routledge , London.

(94) Carmeli, A. and Tishler, A. (2005) Perceived organizational reputation and organizational performance: an empirical investigation of industrial enterprises. Corporate Reputation Review, 8(1), 13-30

(95) Dowling, G. (2004) Journalists' evaluation of corporate reputations. Corporate Reputation Review, 7 (2), $196-205$. 


\section{تحديد العوامل الهامة التي تؤثر في سمعة منظمي الرحلات طبقا لوجهة نظرالأطراف المعنية : أسلوب معامل السمعة}

تسعي الثركات اليوم جاهدة في ظل بيئة العمل الديناميكية و المضطربة التي تتسم بتنافسية عالية إلي البحث عن سبل لتميز عروضهه وبناء علاقات

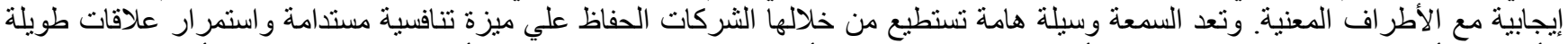

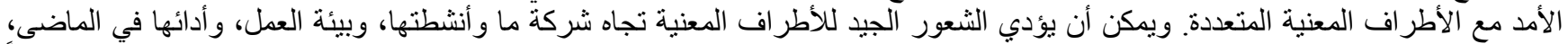

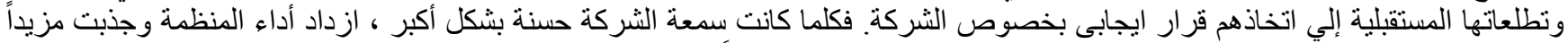

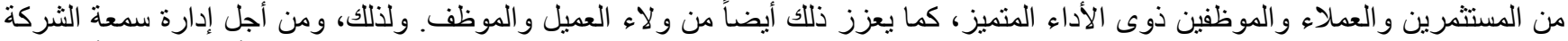

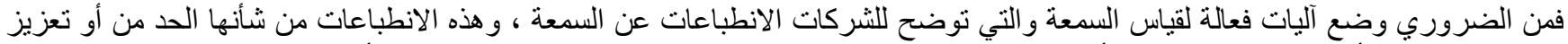

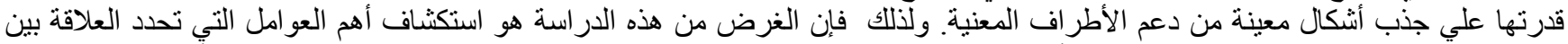

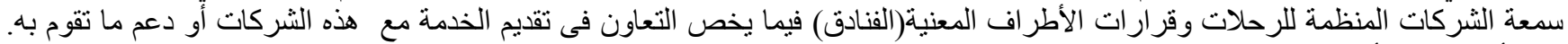

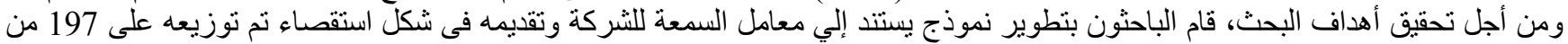

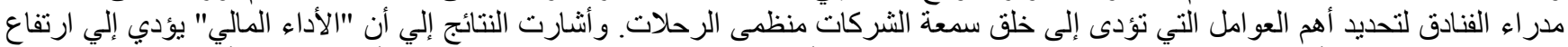

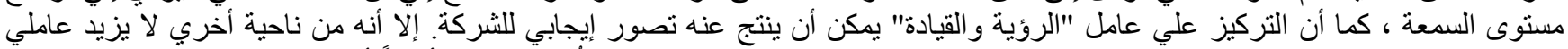

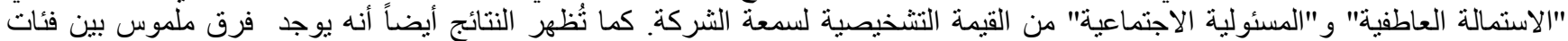

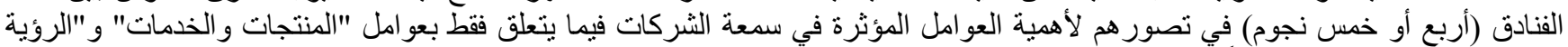

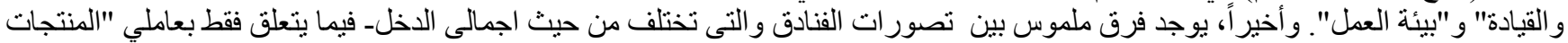

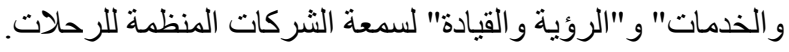

